\title{
Protective effect of Chrysanthemum morifolium Ramat. ethanol extract on lipopolysaccharide induced acute lung injury in mice
}

\author{
Gang Liu*, Qingxiu Zheng, Kunlei Pan and Xiaoxiao Xu
}

\begin{abstract}
Background: To evaluate the effect of Chrysanthemum morifolium Ramat. ethanol extract (CEE) on lipopolysaccharide induced acute lung injury in mice.

Methods: The ninety C57BL/6 J male mice randomly divided into five groups: control, model and CEE (50, 100, 200 $\mathrm{mg} / \mathrm{kg}$ ) groups for 7 days oral administration. At the last administration, all mice except control were intratracheal instilled with lipopolysaccharide (LPS, $3 \mathrm{mg} / \mathrm{kg}$ ) for establish the acute lung injury. Then lung histopathologic, lung wet/ dry weight, white blood cells, lymphocytes, neutrophils were detected. The pro-inflammation cytokine tumor necrosis factor- $a$ (TNF- $\alpha$ ), interleukin (IL)-6, anti-inflammatory cytokine transforming growth factor- $\beta 1$ (TGF- $\beta 1$ ), IL-10 and the marker of antioxides ability total-antioxidant capacity (T-AOC), malondialdehyde (MDA) in lung tissue were measured.

Results: The result showed that CEE could improve lung histopathological injury, reduce the ratio of wet/dry lung weight and lung index, inhibit the increased number of white blood cells, lymphocytes and neutrophils, and reduce the increased levels of TNF- $a$ and IL- 6 . While CEE also significantly increased the levels of TGF- $\beta 1$ and IL-10. Furthermore, CEE also markedly increased the activity of T-AOC, and decreased the contents of MDA with a dose-dependent manner.

Conclusions: The study exhibited that CEE has a potential protective effect on lipopolysaccharide induced acute lung injury in mice, the action mechanism of CEE may through balance of the pro-inflammatory and anti-inflammatory factors, and the oxygen free radicals inhibition.
\end{abstract}

Keywords: Chrysanthemum morifolium Ramat. ethanol extract, Lipopolysaccharide, Acute lung injury, Total triterpenoids, Total flavonoids

\footnotetext{
* Correspondence: gangliu332@163.com

Respiratory Medicine, Wenzhou Chinese Hospital Affiliated to Zhejiang University of Traditional Chinese Medicine, No. 9 Jiaowei Road, Wenzhou 325000, China
}

(c) The Author(s). 2020 Open Access This article is licensed under a Creative Commons Attribution 4.0 International License, which permits use, sharing, adaptation, distribution and reproduction in any medium or format, as long as you give appropriate credit to the original author(s) and the source, provide a link to the Creative Commons licence, and indicate if changes were made. The images or other third party material in this article are included in the article's Creative Commons licence, unless indicated otherwise in a credit line to the material. If material is not included in the article's Creative Commons licence and your intended use is not permitted by statutory regulation or exceeds the permitted use, you will need to obtain permission directly from the copyright holder. To view a copy of this licence, visit http://creativecommons.org/licenses/by/4.0/. The Creative Commons Public Domain Dedication waiver (http://creativecommons.org/publicdomain/zero/1.0/) applies to the data made available in this article, unless otherwise stated in a credit line to the data. 


\section{Background}

Acute lung injury (ALI) refers to acute and progressive hypoxic respiratory failure caused by various external and internal pathogenic factors besides cardiogenic factors [1]. It is characterized by acute progressive dyspnea, decreased lung volume, decreased lung compliance, severe imbalance of ventilation/blood flow ratio, extensive injury of alveolar capillary endothelial cells and alveolar epithelial cells [2]. In 1992, the American Thoracic Society (ATS) and the European Society of Critical Diseases (ESICM) changed ARDS (adult respiratory distress syndrome) to acute, and divided it into two parts: ALI and ARDS [3]. At the same time, the causes of ALI/ARDS were classified into two major factors: direct lung injury and indirect lung injury [4-6]. A large number of clinical studies have shown that Gram-negative bacilli infection is the most common cause of ALI induction and is one of the main causes of death [7, 8]. ALI/ ARDS has become a common critical disease in clinic. However, the pathogenesis of ALI/ARDS has not been fully elucidated [9]. Comprehensive treatment is the main method of clinical treatment, and there is no specific method [10, 11]. Therefore, it is of great practical significance to study the prevention and treatment of ALI/ARDS.

Chrysanthemum morifolium Ramat. is a dry capitate inflorescence, belongs to Compositae [12, 13]. Chrysanthemum morifolium Ramat. was first recorded in "Shen Nong's Herbal Classic" and listed as the top grade, which means it is an effective, safe, non-toxic and harmless medicine [14-16]. $\mathrm{Li}$ et al. reported that the anti-inflammatory and antioxidant properties of CEE in vitro and in vivo [17-19]. It is often used in the clinical treatment of sores, dementia, eye swelling, lung pain, sore throat and flu. Modern pharmacological studies have shown that Chrysanthemum morifolium Ramat. has many pharmacological activities, such as anti-bacterial, anti-virus, anti-inflammatory, anti-oxidation, anti-cancer, treatment of coronary heart disease, lowering blood pressure, prevention of hyperlipidemia, delaying aging and so on [20].

In addition, Chrysanthemum morifolium Ramat. has many active ingredients, such as triterpenoids, flavonoids, volatile oils, organic phenolic acids and so on. It belongs to the antipyretic and detoxicating drugs of traditional medicine [21]. It can be used for sores and poisons, eye and face swelling, lung pain, sore throat and influenza in clinic [22]. Professor Toshihiro Akihisa, a Japanese scholar, has found that a series of triterpenoids, such as dandelion sterols from the non-saponifiable fatsoluble fraction (NSL) of Chrysanthemum morifolium Ramat. ethanol extract (CEE), which possess a significant anti-inflammatory activity $[23,24]$.

Based on the above, Chrysanthemum morifolium Ramat. has a wide pharmacological functions. However, to the best of our knowledge, there have not any research for the effect of CEE on lipopolysaccharide (LPS)-induced ALI in experimental mice. Thus, our study aimed to explore the effect of CEE on LPS-induced ALI in mice, and to investigate whether CEE has a certain medicinal value. The work can provide some experimental data and the theoretical basis for the development of new resources of Chrysanthemum morifolium Ramat. in both clinical medicine and life food in the future.

\section{Methods \\ Materials and reagents}

Malondialdehyde (MDA, Batch No 20180113) and Total antioxidant capacity (T-AOC, Batch No 20180113) purchased from Nanjing Jiancheng Biotechnology Co., Ltd. (Nanjing, China). Tumor necrosis factor-alpha (TNF$\alpha$, Batch No 978941030), interleukin-6 (IL-6, Batch No 1321213119), Transforming growth factor-beta 1 (TGF- $\beta_{1}$, Batch No 9711891103) and interleukin-10 (IL-10, Batch No 1321213121) were purchased from Wuhan Boster Biology Technology co. ltd. (Wuhan, China). LPS obtained from Sigma-Aldrich (Eseherichia coli 055:B5, 818E034, USA).

\section{Preparation of CEE}

The dried Chrysanthemum morifolium Ramat. was purchased from Daguan Chrysanthemum Tea Planting Base in Tongxu County, Qiaofeng City at October 2017, which was identified by Yanli Zhao, an associate researcher of Qiaofeng Agricultural Research Institute. The dried Chrysanthemum morifolium Ramat. was extracted by reflux for $2 \mathrm{~h}$ with $150 \mathrm{~g}$ and 20 times $95 \%$ ethanol, then filtered. The residue was extracted by 18 times $95 \%$ ethanol, and reflux for 3 times, $1.5 \mathrm{~h}$ each time, and combining the three filtrate. Then $95 \%$ ethanol was recovered by decompression and concentrated into extract, which had no alcoholic flavor and was dispersed with appropriate hot water. The extract was extracted with trichloromethane to be colorless and concentrated to extract.

The clinical daily dosage of Chrysanthemum morifolium Ramat. on adults $(60 \mathrm{~kg})$ was $5-10 \mathrm{~g}$. According to the extraction rate of $95 \%$ ethanol (12.31\%), the equivalent amount of the extract per gram was calculated. Then use the equivalent dose coefficient conversion algorithm to calculate the dosage of mice. The extract was prepared with $0.5 \%$ Cluster Methylcellulose Sodium (CMC-Na) solution and stored at $4{ }^{\circ} \mathrm{C}$ for use.

\section{Bioactive constitutes analysis by LC/MS HPLC analysis}

The components of CEE were separated on a Nucleodur $\mathrm{C} 18(4.6 \mathrm{~mm} \times 250 \mathrm{~mm}, 5 \mu \mathrm{m})$ at $35^{\circ} \mathrm{C}$ with the flow rate of $1.0 \mathrm{~mL} / \mathrm{min}$, the detection wavelength was $334 \mathrm{~nm}$. The injection volume was $10 \mu \mathrm{L}$. Mobile phase was include acetonitrile (A) and $0.1 \%$ formic acid-water (B). The gradient program was: $0-5 \mathrm{~min}, 5-18 \% \mathrm{~A} ; 5-30$ min, $18-21 \%$ A; $30-32$ min, $21-38 \%$ A; $32-42$ min, 38- 
45\% A; 42-45 min, $45-60 \%$ A; $45-45.01 \mathrm{~min}, 60 \% \mathrm{~A}-$ 80\%A; 45.01-50 min, 80\%A-85\%A.

\section{Mass spectrum analysis}

The desolvation gas was used nitrogen. The flow rate of the cone gas was $10 \mathrm{~L} / \mathrm{h}$. Capillary voltage was $3 \mathrm{kV}$ for ESI (+) and ESI (-). The temperature of the ion source was $350^{\circ} \mathrm{C}$. Mass spectra were recorded in the range of $\mathrm{m} / \mathrm{z}$ 50-2000 for full scan.

\section{Animals}

Ninety C57BL/6 J male mice (body weight $20 \pm 2 \mathrm{~g}, 8$ weeks) were obtained from the animal experimental center of the Zhejiang University of Traditional Chinese Medicine (China), and the whole experiment was also carried out on Zhejiang University of Traditional Chinese Medicine. The mice were raised at SPF grade environment with $24 \pm 1{ }^{\circ} \mathrm{C}, 50 \% \pm 5 \%$ of humidity and $12 \mathrm{~h}$ day/night cycle. Six mice raised in one polyacrylic cage with free access to food and water. The mice were received humane care in the terms of National Institutes of Health Guidelines of the USA (National Research Council of USA, 1996) and the University ethical regulations of Zhejiang University of Traditional Chinese Medicine.

\section{Experimental design}

The animal study protocol (Protocol number: GL-1801) approved by the animal care and use committee of Zhejiang University of Traditional Chinese Medicine. Ninety C57BL/6 J male mice were randomly divided into 5 groups: the control group, LPS model group, CEE 50, 100 and $200 \mathrm{mg} / \mathrm{kg}$ groups. The mice orally administration with CEE in three dosage, and the control and model mice were administration with the solvent of 0.5\% CMC-Na for 7 days, respectively. At the last time drug administration, the mice were intratracheal instillation of $3 \mathrm{mg} / \mathrm{kg}$ LPS in saline (or with saline as a control) under anesthesia using sodium pentobarbital $(40 \mathrm{mg} / \mathrm{kg})$. After 3, 6 and $24 \mathrm{~h}$ of LPS stimulation, six mice were executed through injection of excessive sodium pentobarbital $(80 \mathrm{mg} / \mathrm{kg})$ at each time point. The blood and lung tissues were harvest for pathological detection.

\section{Histopathological analysis}

The right lower lung was fixed with $4 \%$ polymethanol solution, then the lung tissue was dehydrated routinely, paraffin-embedded, sliced (thickness $5 \mu \mathrm{m}$ ), hematoxylineosin (H\&E) stained, xylene transparent, neutral gum sealed to make paraffin-embedded pathological sections. Optical microscopy was used to observe whether the alveolar wall was thickened, hyperemia, inflammatory cell infiltration, interstitial inflammation, edema, alveolar necrosis and bleeding.
Effect of CEE on cell numbers of the whole white blood and the classified cells

Blood samples were taken from eyeballs of mice in each group. Take $10 \mu \mathrm{L}$ of blood samples from mice to EP tube containing $800 \mu \mathrm{L}$ haemocyte dilution solution. The whole white blood and the classified cells were measured by automatic blood analyzer.

\section{Detection of wet/dry lung weight ratio, left lung dry weight/ body weight ratio and lung index in lung injury mice}

After eyeball bleeding, the mice were killed by cervical dislocation, then fixed on the operating table. After trachea exposure, the thoracic cavity was opened to observe the morphological changes of lungs. Then all the lungs were taken out and the wet weight of the whole lungs was weighed to calculate the lung index (lung index $\%=$ wet lung weight/body weight $\times 10^{3}$ ). After separating the left lung, weighing the wet weight, drying it in $60^{\circ} \mathrm{C}$ blast drying box for $48 \mathrm{~h}$ to constant weight, taking out and precise fixed dry weight to calculate the wet/dry lung weight ratio (W/D) and the dry lung weight/body weight ratio of the left lung, which is mainly used to reflect the degree of pulmonary edema.

Detection of pro-inflammation cytokine (TNF- $a, \mathrm{IL}-6)$ and anti-inflammatory cytokine (TGF- $\beta 1$, IL-10) in lung tissue of mice by ELISA

Pre-cooled phosphate buffer saline (PBS) was used to prepare $10 \%$ lung tissue homogenate by electric homogenizer on ice. The expression levels of TNF- $\alpha$, IL-6, TGF- $\beta 1$ and IL-10 in lung tissue were detected by ELISA method according to the instruction of each kit from Wuhan Boster Biology Technology co. ltd. (Wuhan, China), respectively.

\section{Determination of the activity of T-AOC and the contents of MDA in lung tissue of mice}

The lung tissue of mice was fully homogenized in an electric homogenizer with pre-cooled physiological saline, and $10 \%$ lung tissue homogenate was prepared according to the kit protocol from Nanjing Jiancheng Biotechnology Co., Ltd. (Nanjing, China).

\section{Statistical analysis}

The present biological data were represented as mean \pm SD . All statistical comparisons were calculated by means of a one-way ANOVA test followed by Dunett's t-test with GraphPad Prism 6.0 statistical software. $P<0.05$ and $<0.01$ were regarded as statistically significant.

\section{Results}

Observation of mice symptoms

In control group, the mice were in good mental and developmental state, with normal feeding and drinking 
water, bright coat and normal feces. The mice in the model group had symptoms of reduced autonomic activity, mental depression, dyspnea, and accumulated with each other. At the same time, mucous substances were emitted from the mouth and nose, and severe diarrhea occurred. The intake of food and drinking water decreased significantly. Compared with the model group, the symptoms of CEE high dose group were significantly improved, while the symptoms of low dose group were slightly alleviated.
Effect of CEE on the whole white cells and the clarified cells in lung injury mice

The increased numbers of white blood cells, lymphocytes and neutrophils related to the immunity and inflammation in the blood indicates that the body has an inflammatory response. Compared with the control group, the total number of the white blood cells, lymphocyte and neutrophils in the model group increased significantly at $3 \mathrm{~h}$ after modeling (Fig. $1, P<0.01)$. Compared with model group, CEE
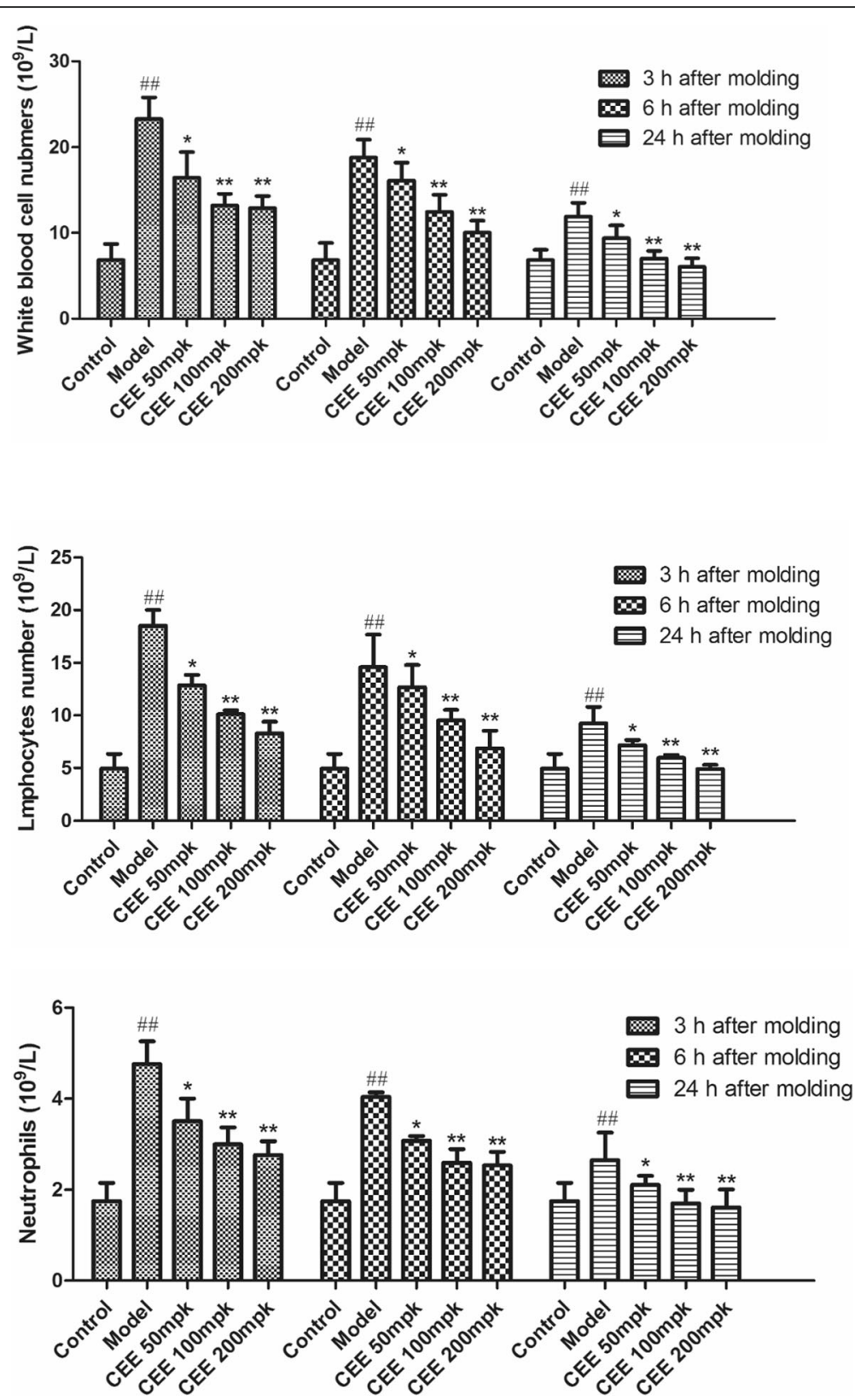

Fig. 1 Effect of CEE on white blood cells in BALF of ALI mice $(n=18) .{ }^{\# \#} P<0.01$ vs normal group, ${ }^{*} P<0.05,{ }^{* *} P<0.01$ vs model group. CEE: Chrysanthemum morifolium Ramat. ethanol extract; ALl: acute lung injury 
in high, middle and low dose groups could significantly reduce the numbers of white blood cells, lymphocyte and neutrophils (Fig. $1, P<0.05, P<$ 0.01 ). While at $6 \mathrm{~h}$ and $24 \mathrm{~h}$ after modeling, the number of white blood cells, lymphocyte and neutrophils was still significantly higher than that of control group. The three doses of CEE showed a significantly inhibition the inflammatory reaction in varying degrees (Fig. $1, P<0.05, P<0.01$ ).
Effect of CEE on lung index, left lung wet/dry weight ratio and left lung dry/body weight ratio in mice ALI

Lung wet/dry weight ratio is used to evaluate the degree of lung edema. In Fig. 2, we can see that the lung index, lung wet/dry weight ratio and the lung dry/body weight ratio were significantly increased in each time point, compared with the control group (Fig. 2, $P<0.01$ ). While all the three dosages of CEE could markedly reduce the lung index, the ratio of
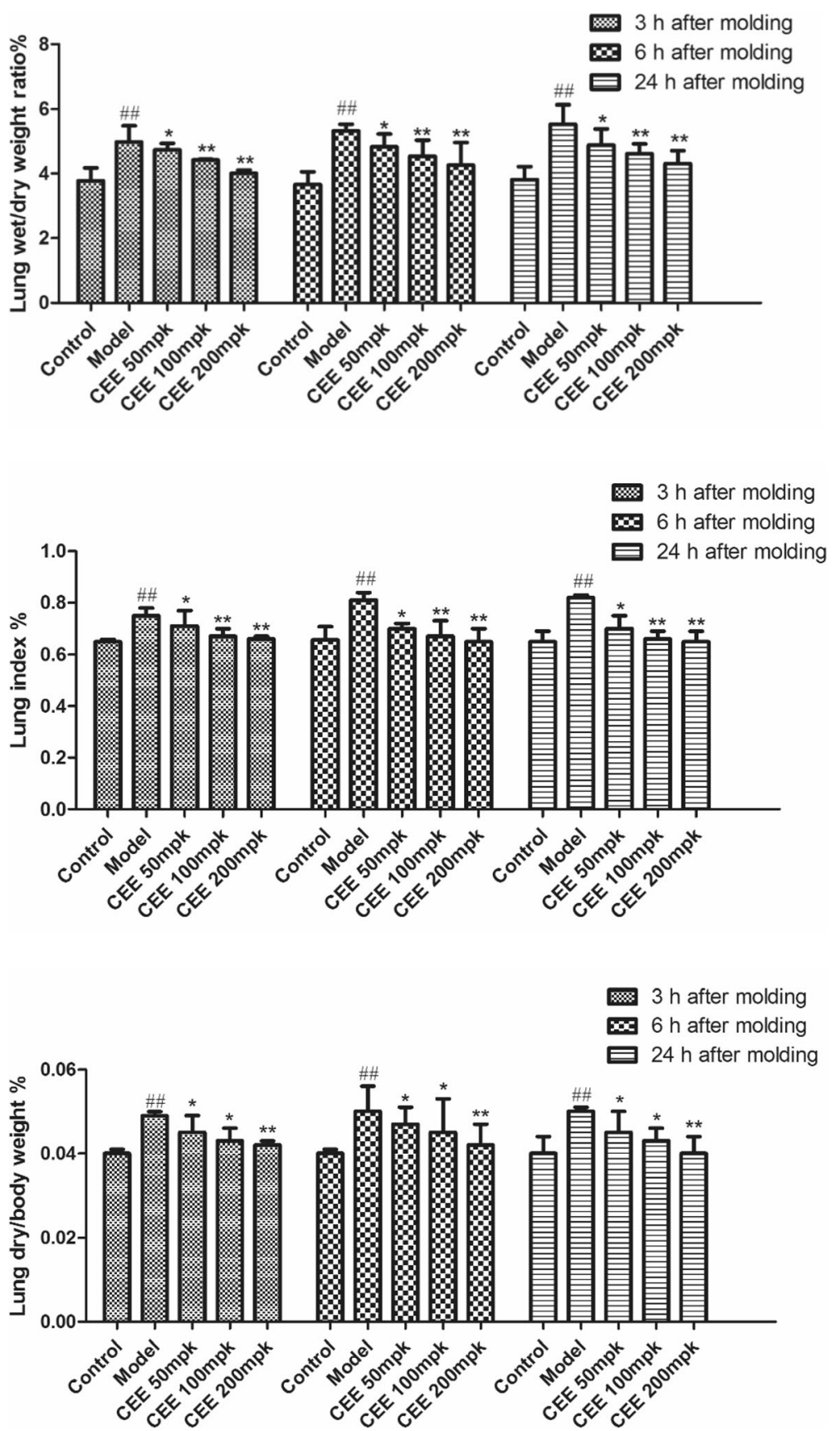

Fig. 2 Effect of CEE on lung wet/dry weight ratio, lung index and lung dry/body weight ratio in ALI mice $(\mathrm{n}=18)$. ${ }^{\#} P<0.01$ vs normal group, ${ }^{*} P<0.05,{ }^{* *} P<0.01$ vs model group. CEE: Chrysanthemum morifolium Ramat. ethanol extract; ALl: acute lung injury 
lung wet/dry weight and lung dry/body weight ratio at the time point of 3,6 and $24 \mathrm{~h}$, compared with the model group (Fig. 2, $P<0.05, P<0.01$ ), especially the high dose of CEE treated groups. This result reflected that CEE could alleviate lung edema in various degree.

\section{CEE improves lung histopathology in lung injury mice}

Under the light microscopy of H\&E section (Fig. 3), the alveolar cavity structure of control group was clear, alveolar wall was thin, and there was no obvious hyperemia and no neutrophil infiltration (Fig. 3a). In the model group, the lung tissue structure changed, alveolar wall was discontinuous, alveolar cavity disappeared in large area, alveolar wall became thicker, a large number of neutrophils and giant cells infiltrated the lungs, and there were obvious congestion and edema in the alveolar cavity, which also proved that the model of acute lung injury was successful (Fig. 3b). In CEE high, middle and low dose groups, the pathological changes were improved, the structure of the lung tissue was clear gradually, and the infiltration of pulmonary interstitium was improved significantly, especially in high dose group (Fig. 3c, d, e).
Effect of CEE on the expression of TNF- $a$, IL-6, TGF- $\beta 1$ and IL-10 in lung tissue of lung injury mice

Table 1 showed the levels of pro-inflammatory factor TNF- $\alpha$ and IL- 6 in each groups.

After modeling $3 \mathrm{~h}$, the levels of TNF- $\alpha$ and IL- 6 in model group were significantly increased, compared with the control group (Table $1, P<0.01$ ), which reflect that the model was successfully established. At the $6 \mathrm{~h}$ after modeling, the levels of IL- 6 still increasing, while TNF- $\alpha$ levels start decrease in model group, compared with the model group in $3 \mathrm{~h}$. At the $24 \mathrm{~h}$ after modeling, the levels of TNF- $\alpha$ and IL- 6 in model group were decreasing compared with the levels in $3 \mathrm{~h}$. However, the levels of TNF- $\alpha$ and IL-6 in model group at 6 and $24 \mathrm{~h}$ still significantly higher than the control group (Table 1, $P<0.01$ ). CEE treated groups were significantly reduced the levels of TNF- $\alpha$ and IL-6, compared with the model group (Table $1, P<0.05, P<0.01$ ).

In addition, the levels of anti-inflammation factor TGF$\beta 1$ and IL-10 showed in Fig. 4. The result showed that at the time point of 3 and $6 \mathrm{~h}$, the levels of TGF- $\beta 1$ and IL-10 were significantly increased, compared with the control group (Fig. $4, P<0.05, P<0.01$ ). CEE treated group could dramatically increase the levels of TGF- $\beta 1$ and IL-10,
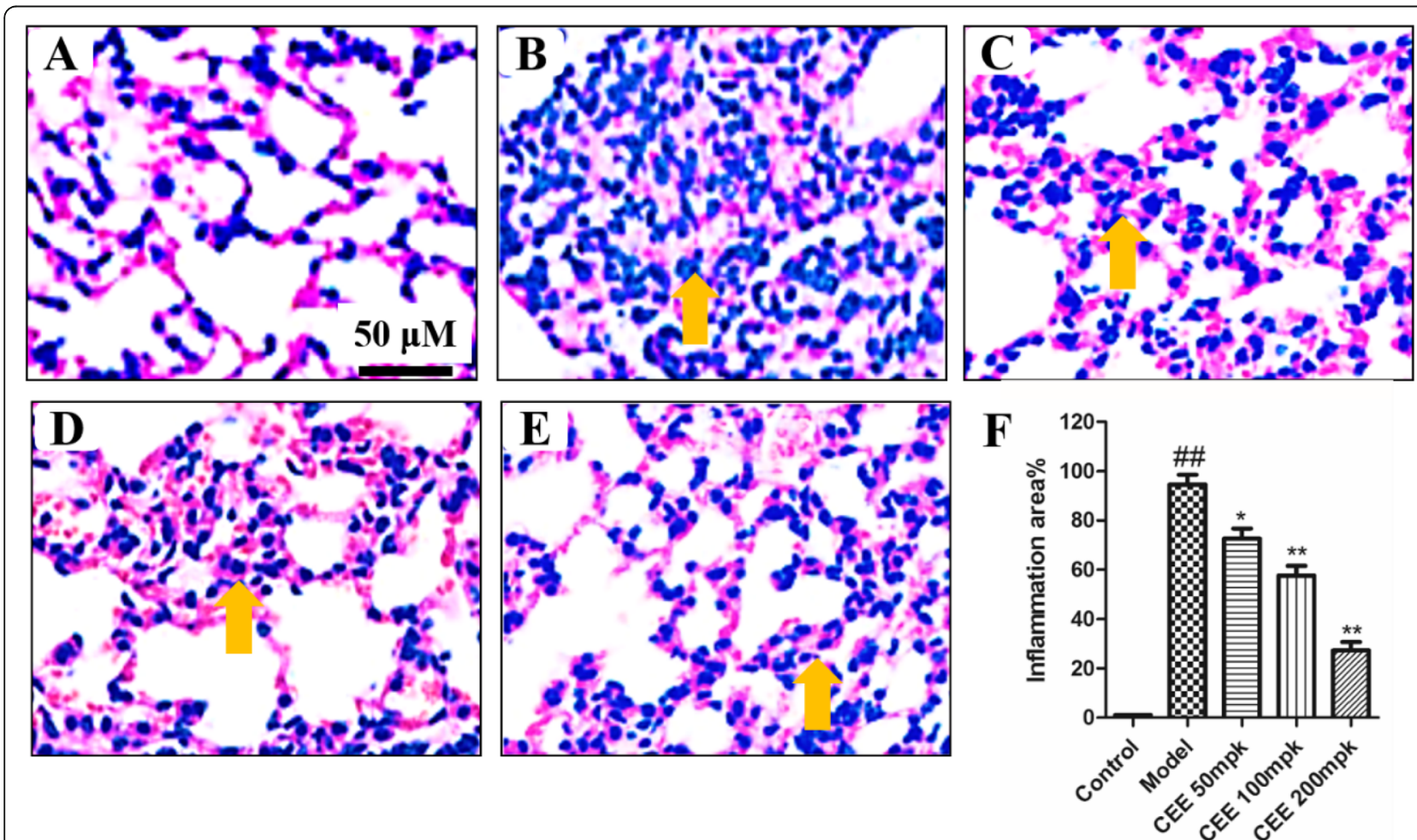

Fig. 3 Effect of CEE on lung histopathology in ALI mice (H\&E, Scale bar $50 \mu \mathrm{m})$. a. vehicle group, b. LPS model group, c. CEE $10 \mathrm{mg} / \mathrm{kg}$, d. CEE 30 $\mathrm{mg} / \mathrm{kg}$ e. CEE $60 \mathrm{mg} / \mathrm{kg}$. f. the statistical data of the inflammation areas in each group. CEE: Chrysanthemum morifolium Ramat. ethanol extract; ALI, acute lung injury 
Table 1 Effect of CEE on the levels of TNF- $a$ and IL-6 in ALI mice

\begin{tabular}{|c|c|c|c|}
\hline \multirow[t]{2}{*}{ Group } & \multirow[t]{2}{*}{ Dose } & \multicolumn{2}{|l|}{$3 \mathrm{~h}$ after molding } \\
\hline & & TNF-a $(n g / g)$ & IL-6 (ng/g) \\
\hline Normal & - & $363.35 \pm 41.80$ & $60.06 \pm 5.93$ \\
\hline Model & - & $539.5 \pm 20.4^{\# \#}$ & $101.31 \pm 13.65^{\# \#}$ \\
\hline CEE-low & $50 \mathrm{mg} / \mathrm{kg}$ & $482.75 \pm 41.98^{* *}$ & $95.62 \pm 9.17^{*}$ \\
\hline CEE-medium & $100 \mathrm{mg} / \mathrm{kg}$ & $444.83 \pm 12.11^{* *}$ & $90.10 \pm 5.11^{* *}$ \\
\hline \multirow[t]{2}{*}{ CEE-high } & $200 \mathrm{mg} / \mathrm{kg}$ & $437.55 \pm 12.12^{* *}$ & $80.00 \pm 8.74^{* *}$ \\
\hline & & \multicolumn{2}{|l|}{$6 \mathrm{~h}$ after molding } \\
\hline Normal & - & $363.42 \pm 31.12$ & $59.35 \pm 5.47$ \\
\hline Model & - & $511.45 \pm 31.9^{\# \#}$ & $112.63 \pm 5.01^{\# \#}$ \\
\hline CEE-low & $50 \mathrm{mg} / \mathrm{kg}$ & $462.60 \pm 18.11^{*}$ & $79.89 \pm 10.12$ \\
\hline CEE-medium & $100 \mathrm{mg} / \mathrm{kg}$ & $416.32 \pm 19.62^{*}$ & $71.18 \pm 4.76^{*}$ \\
\hline \multirow[t]{2}{*}{ CEE-high } & 200 mg/kg & $407.35 \pm 4.99^{* *}$ & $65.78 \pm 9.20^{* *}$ \\
\hline & & \multicolumn{2}{|l|}{$24 \mathrm{~h}$ after molding } \\
\hline Normal & - & $362.49 \pm 30.43$ & $60.21 \pm 4.86$ \\
\hline Model & - & $500.5 \pm 20.4^{\# \#}$ & $106.78 \pm 9.13^{\# \#}$ \\
\hline CEE-low & $50 \mathrm{mg} / \mathrm{kg}$ & $419.33 \pm 8.92^{* *}$ & $75.34 \pm 13.53^{*}$ \\
\hline CEE-medium & 100 mg/kg & $392.00 \pm 21.38^{* *}$ & $65.39 \pm 9.23^{* * *}$ \\
\hline CEE-high & $200 \mathrm{mg} / \mathrm{kg}$ & $380.05 \pm 12.43^{* *}$ & $62.41 \pm 10.27^{* *}$ \\
\hline
\end{tabular}

Data are present as mean $\pm \mathrm{SD}(\mathrm{n}=18) .{ }^{\# \#} P<0.01$ vs normal group, ${ }^{*} P<0.05,{ }^{* *} P<0.01$ vs model group. CEE: Chrysanthemum morifolium Ramat. ethanol extract; ALI: acute lung injury
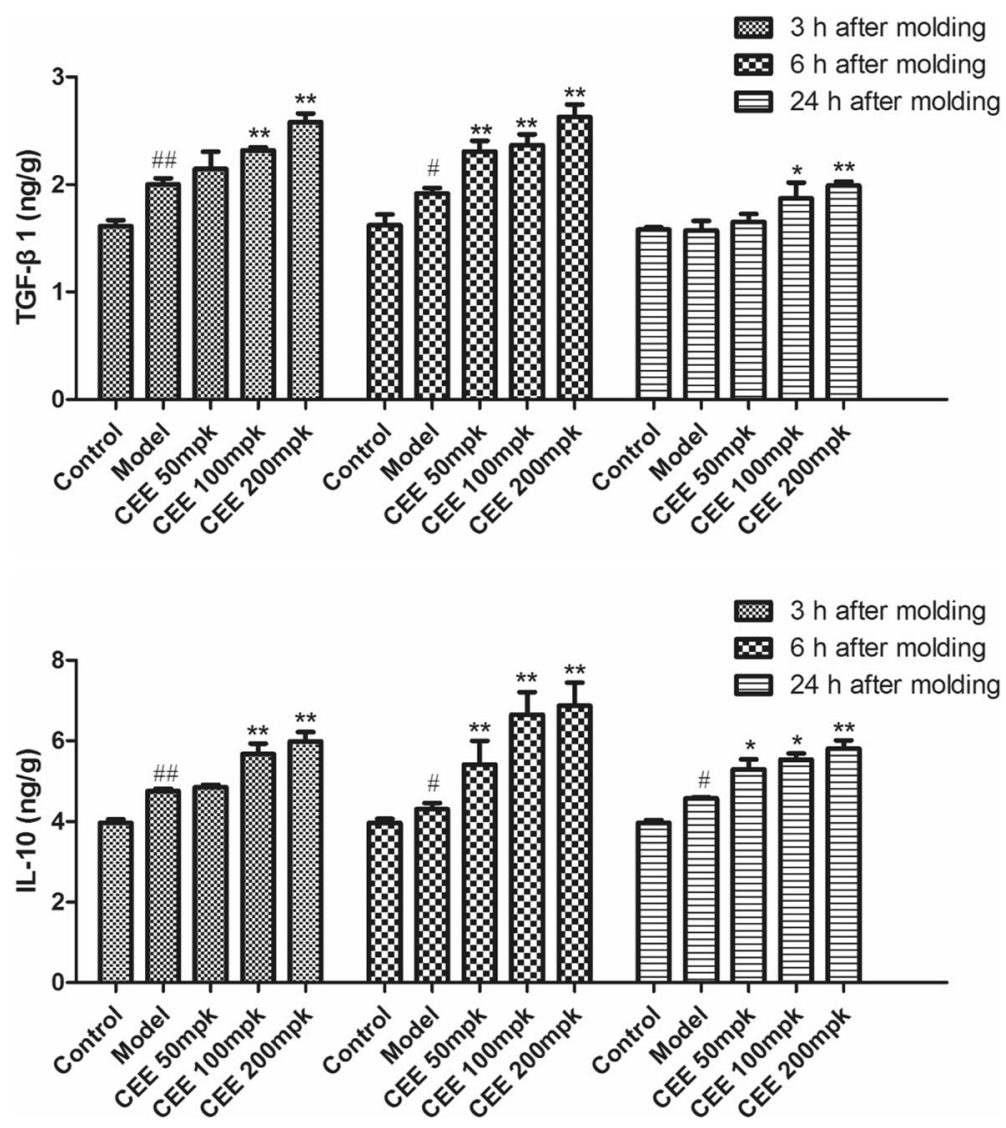

Fig. 4 Effect of CEE on the levels of TGF- $\beta 1$ and IL-10 in lung tissue of ALI mice $(n=18)$. ${ }^{\# \#} P<0.01$ vs normal group, ${ }^{*} P<0.05,{ }^{* * *} P<0.01$ vs model group. CEE: Chrysanthemum morifolium Ramat. ethanol extract; ALI, acute lung injury 
compared with the model group (Fig. $4, P<0.05, P<0.01$ ). While at $24 \mathrm{~h}$, there was no obvious increase for the levels of TGF- $\beta 1$ in model group, while CEE treated group still could increase the TGF- $\beta 1$ levels, compared with model group, especially in the high dose of CEE (Fig. $4, P<0.05$, $P<0.01)$. Furthermore, IL-10 levels in model group at $24 \mathrm{~h}$ still higher than the control group (Fig. $4, P<0.05$ ). While the CEE treated groups also showed an increase in the levels of IL-10, compared with the model group (Fig. $4, P<0.05, P<0.01$ ).

\section{Effect of CEE on the activity of T-AOC and MDA contents in lung tissue of lung injury mice}

In Table 2, it can be seen that the MDA content in lung tissue of model group increased significantly at each time point, compared with control group (Table $2, P<$ 0.01). Compared with model group, the high, medium and low dosages of CEE groups could reduce the increase of MDA content in lung tissue (Table 2, $P<0.05$, $P<0.01)$. At each time point, compared with the control group, the activity of T-AOC was significantly decreased in model group (Table 2, $P<0.01$ ). Compared with model group, CEE treated groups could markedly increase T-AOC activity in lung tissue, especially the high dose of CEE treated group (Table 2, $P<0.05, P<0.01$ ). The result exhibited that CEE has an antioxidant effect in lung tissue for lung injury mice.

\section{Bioactive component identification of CEE}

Through the total ion chromatogram of CEE analysis, we have totally identified 12 components (Fig. 5) from CEE, they are neochlorogenic acid (1), chlorogenic acid (2), caffeic acid (3), 1,3-dicaffeoylquinic acids (4), cynaroside (5), isochlorogenic acid $C$ (6), isochlorogenic acid A (7), isochlorogenic acid B (8), linarin (9), luteolin (10), apigenin (11), acacetin (12). We also compared the chromatograph peaks of the mixed standard compounds and the samples of CEE (Fig. 5a, b and c).

\section{Discussion}

Endotoxin is a lipopolysaccharide (LPS) component of the outer membrane of Gram-negative bacilli [25]. It can cause alveolar epithelial cell injury and changes in lung structure and function, and enter the body to establish an ALI model after infection [26]. The direct consequence of ALI is alveolar edema, increased permeability, and the degree of microcirculation disorder in lung tissue, which can directly reflect the degree of lung injury [27]. Pulmonary microcirculation disturbance is mainly caused by structural changes and functional impairment of pulmonary vascular endothelial cells. Thus, the permeability of capillary is an index to judge pulmonary microcirculation disturbance. Lung wet/dry ratio, lung index and lung dry/body weight ratio of lung tissue can objectively reflect the relative degree of capillary permeability $[27,28]$. In our study, the results showed that the

Table 2 Effect of CEE on the levels of T-AOC and MDA in ALI mice

\begin{tabular}{|c|c|c|c|}
\hline \multirow[t]{2}{*}{ Group } & \multirow[t]{2}{*}{ Dose } & \multicolumn{2}{|l|}{$3 \mathrm{~h}$ after molding } \\
\hline & & T-AOC (U/mgprot) & MDA (nmol/mgprot) \\
\hline Normal & - & $2.78 \pm 0.23$ & $3.34 \pm 0.39$ \\
\hline Model & - & $0.98 \pm 0.06^{\# \#}$ & $6.18 \pm 0.31^{\# \#}$ \\
\hline CEE-low & $50 \mathrm{mg} / \mathrm{kg}$ & $1.28 \pm 0.08^{*}$ & $5.13 \pm 0.03^{*}$ \\
\hline CEE-medium & $100 \mathrm{mg} / \mathrm{kg}$ & $1.97 \pm 0.32^{* *}$ & $4.65 \pm 0.12^{* *}$ \\
\hline \multirow[t]{2}{*}{ CEE-high } & $200 \mathrm{mg} / \mathrm{kg}$ & $2.05 \pm 0.13^{* *}$ & $4.26 \pm 0.21^{* *}$ \\
\hline & & \multicolumn{2}{|l|}{$6 \mathrm{~h}$ after molding } \\
\hline Normal & - & $2.79 \pm 0.22$ & $3.35 \pm 0.30$ \\
\hline Model & - & $0.98 \pm 0.08^{\# \#}$ & $6.23 \pm 0.25^{\# \#}$ \\
\hline CEE-low & 50 mg/kg & $1.27 \pm 0.10^{*}$ & $5.15 \pm 0.05^{*}$ \\
\hline CEE-medium & $100 \mathrm{mg} / \mathrm{kg}$ & $1.96 \pm 0.42^{* *}$ & $4.66 \pm 0.33^{* *}$ \\
\hline \multirow[t]{2}{*}{ CEE-high } & $200 \mathrm{mg} / \mathrm{kg}$ & $2.00 \pm 0.08^{* *}$ & $4.01 \pm 0.53^{* *}$ \\
\hline & & \multicolumn{2}{|l|}{$24 \mathrm{~h}$ after molding } \\
\hline Normal & - & $2.79 \pm 0.46$ & $3.39 \pm 0.19$ \\
\hline Model & - & $0.94 \pm 0.02^{\# \#}$ & $6.25 \pm 0.45^{\# \#}$ \\
\hline CEE-low & $50 \mathrm{mg} / \mathrm{kg}$ & $1.25 \pm 0.05^{*}$ & $5.18 \pm 0.09^{*}$ \\
\hline CEE-medium & $100 \mathrm{mg} / \mathrm{kg}$ & $2.07 \pm 0.32^{* *}$ & $4.68 \pm 0.42^{* *}$ \\
\hline CEE-high & $200 \mathrm{mg} / \mathrm{kg}$ & $2.58 \pm 0.03^{* *}$ & $4.00 \pm 0.32^{* *}$ \\
\hline
\end{tabular}

Data are present as mean $\pm S D(n=18) .{ }^{\# \#} P<0.01$ vs normal group, ${ }^{*} P<0.05,{ }^{* *} P<0.01$ vs model group. CEE: Chrysanthemum morifolium Ramat. ethanol extract; ALI: acute lung injury 


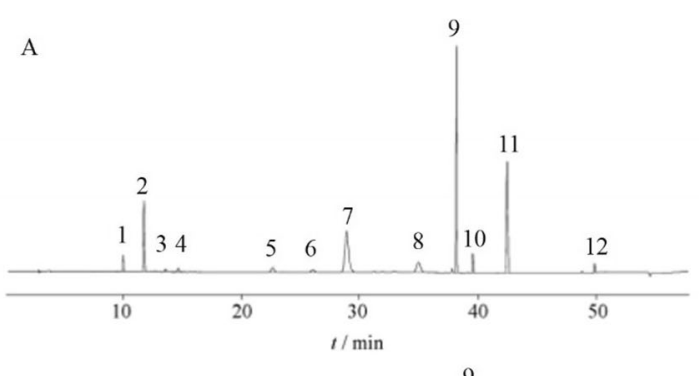

B
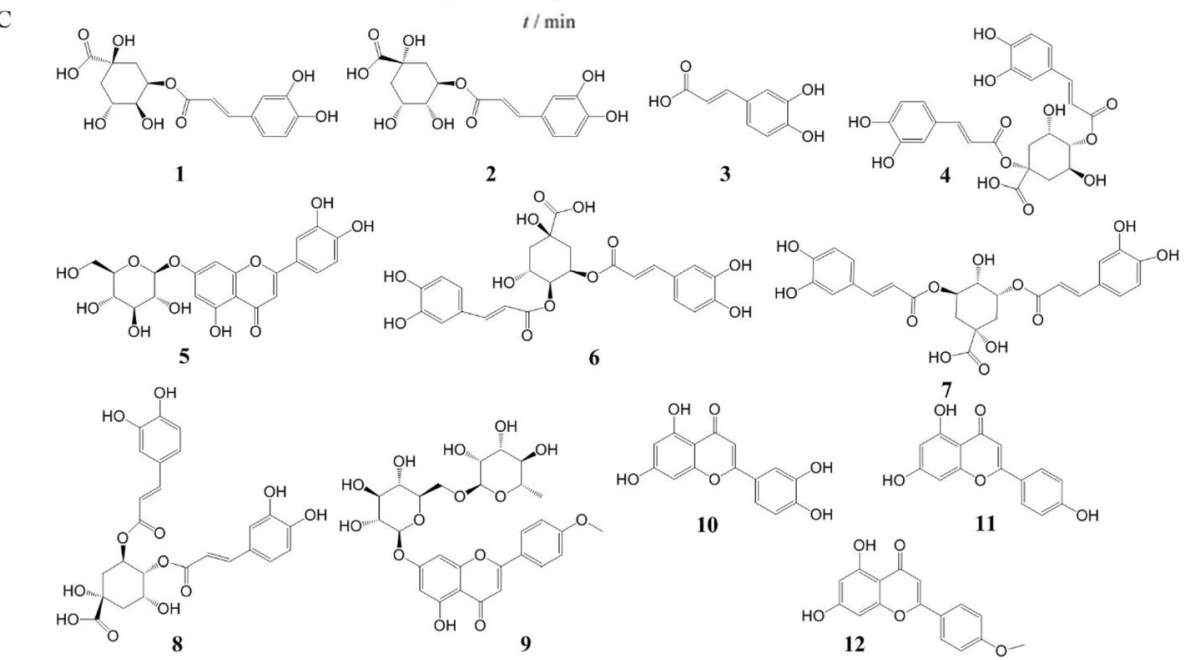

Fig. 5 Bioactive constitutes of CEE. a. the HPLC chromatograph of the standard compounds 1-12. b. the HPLC chromatograph of CEE. c. the chemical structures of compounds 1-12: Neochlorogenic acid (1), chlorogenic acid (2), caffeic acid (3), 1,3-dicaffeoylquinic acids (4), cynaroside (5), isochlorogenic acid C (6), isochlorogenic acid A (7), isochlorogenic acid B (8), linarin (9), luteolin (10), apigenin (11) and acacetin (12)

water content in lung tissue of model mice increased significantly after LPS modeling, suggesting that the pulmonary capillary permeability increased significantly under acute lung injury. At three-time point, CEE (50, 100 and $200 \mathrm{mg} / \mathrm{kg}$ ) could significantly reduce the lung wet/dry ratio, lung index and lung dry/body weight ratio. It can be concluded that CEE can reduce the permeability of pulmonary capillaries, improve pulmonary microcirculation, and then alleviate LPS-induced lung injury in ALI mice.

When the body stimulated by LPS, the activated macrophages will release a large number of pro-inflammatory cytokines such as TNF- $\alpha$, IL- 6 and IL- $1 \beta$, which further induce neutrophils to migrate, aggregate in the interstitial and alveolar cavity, and produce respiratory bursts after the activation of aggregated neutrophils, leading to lung-lung eruption, and a series of lung tissue injuries, such as vascular congestion, pulmonary edema, alveolar atrophy, etc. [7, 29]. At the same time, compensatory anti-inflammatory response is also carried out, releasing endogenous anti-inflammatory factors such as soluble tumor necrosis factor receptor (sTNFR), interleukin-1 receptor antagonist (IL-1ra), IL-10 and TGF- $\beta 1$ to achieve the balance of anti-inflammatory/inflammatory $[27,28,30]$. Therefore, whether drugs can inhibit inflammatory factors, increase anti-inflammatory factors, regulate the balance between inflammatory factors and anti-inflammatory factors in ALI, to achieve the goal of treating ALI. Therefore, in this study, we detected the levels of TNF- $\alpha$, IL-6, TGF- $\beta 1$ and IL-10 in lung tissue of mice. We observed that CEE can reduce the levels of TNF- $\alpha$ and IL- 6 in lung tissue and increase the levels of TGF- $\beta 1$ and IL-10. It is suggested that the protective effect of CEE on LPS-induced ALI is related to regulating the antiinflammatory/inflammatory balance of ALI. 
Furthermore, we also detected the oxidation and antioxidation activities in lung tissue of ALI mice. We found that CEE could also increase the activity of T-AOC, and reduce the lipid peroxidation products MDA contents, which reflect that CEE could also balance the oxidation/ anti-oxidation in ALI mice. In addition, from the bioactive constitutes analysis, we found that the main chemical constitutes of CEE are flavonoids, phenolic acids and terpenoids.

\section{Conclusion}

In conclusion, CEE showed a potential protective effect on lipopolysaccharide induced acute lung injury in mice, the protective mechanism of CEE may through the balance of the pro-inflammatory and anti-inflammatory factors, and the oxygen free radicals inhibition. While the bioactive constitues of CEE mainly focuses on flavonoids, phenolic acids and terpenoids.

\section{Abbreviations \\ CEE: Chrysanthemum morifolium Ramat. ethanol extract; \\ LPS: Lipopolysaccharide; ALI: Acute lung injury; ATS: American Thoracic Society; ESICM: European Society of Critical Diseases; ARDS: Adult respiratory distress syndrome; TNF-a: Tumor necrosis factor-alpha; IL-6: Interleukin-6; TGF- $\beta_{1}$ : Transforming growth factor-beta 1; IL-10: Interleukin-10; H\&E: Hematoxylin-eosin; CMC-Na: Cluster Methylcellulose Sodium; PBS: Phosphate buffer saline; DIC: Disseminated intravascular coagulation; STNFR: soluble tumor necrosis factor receptor; IL-1 ra: Interleukin-1 receptor antagonist}

\section{Acknowledgements}

We are thanks the animal facility of Zhejiang University of Traditional Chinese Medicine for the animal care.

\section{Authors' contributions}

GL guaranteed the whole experiment studies; GL, QZ, KP and XX carried out all the experiments include the design of the study, the statistical analysis and the manuscript writing; GL, QZ and KP edited and revised the whole manuscript; all authors read and approved the final manuscript.

\section{Funding}

No application.

\section{Availability of data and materials}

The datasets used and/or analyzed during the current study are available from the corresponding author on reasonable request.

\section{Ethics approval and consent to participate}

All the animal study protocols were approved by the animal care and use committee of Zhejiang University of Traditional Chinese Medicine, China (GL1801).

\section{Consent for publication}

Not applicable.

\section{Competing interests}

The authors declare that they have no conflict interest.

Received: 8 March 2020 Accepted: 6 July 2020

Published online: 25 July 2020

\section{References}

1. Butt $Y$, Kurdowska A, Allen TC. Acute lung injury: a clinical and molecular review. Arch Pathol Lab Med. 2016;140(4):345-50.
2. Rebetz J, Semple JW, Kapur R. The pathogenic involvement of neutrophils in acute respiratory distress syndrome and transfusion-related acute lung injury. Transfus Med Hemother. 2018;45(5):290-8.

3. Dries DJ. ARDS from syndrome to disease-treatment strategies. Air Med J. 2019;38(2):64-7.

4. Chen $M$, Lu J, Chen $Q$, Cheng L, Geng $Y$, Jiang $H$, Wang X. Statin in the treatment of ALI/ARDS: a systematic review and meta-analysis based on international databases. Zhonghua Wei Zhong Bing Ji Jiu Yi Xue. 2017;29(1):51-6.

5. Prasertsan P, Anuntaseree W, Ruangnapa K, Saelim K, Geater A. Severity and mortality predictors of pediatric acute respiratory distress syndrome according to the pediatric acute lung injury consensus conference definition. Pediatric Crit Care Med. 2019;20(10):e464-72.

6. Oakley C, Koh M, Baldi R, Soni S, O'Dea K, Takata M, Wilson M. Ventilation following established ARDS: a preclinical model framework to improve predictive power. Thorax. 2019;74(12):1120-9.

7. Li Q, Sun M, Wan Z, Liang J, Betti M, Hrynets Y, Xue X, Wu L, Wang K. Bee pollen extracts modulate serum metabolism in lipopolysaccharide-induced acute lung injury mice with anti-inflammatory effects. J Agric Food Chem. 2019;67(28):7855-68

8. Ni YN, Chen G, Sun J, Liang BM, Liang ZA. The effect of corticosteroids on mortality of patients with influenza pneumonia: a systematic review and meta-analysis. Crit Care. 2019;23(1):99.

9. Siddiqui MT, Litts JK, Cheney DM, Kuhn MA, Nativ-Zeltzer N, Belafsky PC. The effect of aspirated barium sulfate, iodixanol, and diatrizoic acid on survival and lung injury in a lagomorph model. Laryngoscope. 2017; 127(5):E148-52.

10. McIntyre LA, Moher D, Fergusson DA, Sullivan KJ, Mei SH, Lalu M, Marshall J, McLeod M, Griffin G, Grimshaw J, et al. Efficacy of Mesenchymal stromal cell therapy for acute lung injury in preclinical animal models: a systematic review. PLoS One. 2016;11(1):e0147170.

11. Lalu MM, Moher D, Marshall J, Fergusson D, Mei SH, Macleod M, Griffin G, Turgeon AF, Rudnicki M, Fishman J, et al. Efficacy and safety of mesenchymal stromal cells in preclinical models of acute lung injury: a systematic review protocol. Syst Rev. 2014;3:48.

12. Nabeshima T, Doi M, Hosokawa M. Comparative analysis of Chrysanthemum stunt viroid accumulation and movement in two Chrysanthemum (Chrysanthemum morifolium) cultivars with differential susceptibility to the viroid infection. Front Plant Sci. 2017;8:1940.

13. Nabeshima T, Matsushita Y, Hosokawa M. Chrysanthemum stunt viroid resistance in chrysanthemum. Viruses. 2018;10(12).719.

14. Ohmiya A. Molecular mechanisms underlying the diverse array of petal colors in chrysanthemum flowers. Breed Sci. 2018;68(1):119-27.

15. Lu GP, Wang YX. Drug management of pediatric acute respiratory distress syndrome. Zhongguo Dang Dai Er Ke Za Zhi. 2018;20(9):697-700.

16. Song XY, Li YD, Shi YP, Jin L, Chen J. Quality control of traditional Chinese medicines: a review. Chin J Nat Med. 2013;11(6):596-607.

17. Cho WK, Jo Y, Jo KM, Kim KH. A current overview of two viroids that infect chrysanthemums: Chrysanthemum stunt viroid and Chrysanthemum chlorotic mottle viroid. Viruses. 2013;5(4):1099-113.

18. Li Y, Yang P, Luo Y, Gao B, Sun J, Lu W, Liu J, Chen P, Zhang Y, Yu LL. Chemical compositions of chrysanthemum teas and their anti-inflammatory and antioxidant properties. Food Chem. 2019;286:8-16.

19. Yang L, Nuerbiye A, Cheng P, Wang JH, Li H. Analysis of Floral Volatile Components and Antioxidant Activity of Different Varieties of Chrysanthemum morifolium. Molecules. 2017;22(10):1790.

20. Matsuda K. Pyrethrin biosynthesis and its regulation in Chrysanthemum cinerariaefolium. Top Curr Chem. 2012;314:73-81.

21. Wang C. Advances in the study on chemical constituents of Chrysanthemum morifolium Ramat. Zhong Yao Cai. 2004;27(3):224-6.

22. Hitmi A, Coudret A, Barthomeuf C. The production of pyrethrins by plant cell and tissue cultures of Chrysanthemum cinerariaefolium and Tagetes species. Crit Rev Biochem Mol Biol. 2000;35(5):317-37.

23. Akihisa T, Franzblau SG, Ukiya M, Okuda H, Zhang F, Yasukawa K, Suzuki T, Kimura $Y$. Antitubercular activity of triterpenoids from Asteraceae flowers. Biol Pharm Bull. 2005;28(1):158-60.

24. Ukiya M, Akihisa T, Tokuda H, Suzuki H, Mukainaka T, Ichiishi E, Yasukawa K, Kasahara Y, Nishino H. Constituents of Compositae plants III. Anti-tumor promoting effects and cytotoxic activity against human cancer cell lines of triterpene diols and triols from edible chrysanthemum flowers. Cancer Lett. 2002;177(1):7-12. 
25. Dong Y, Zhang L, Jiang Y, Dai J, Tang L, Liu G. Emodin reactivated autophagy and alleviated inflammatory lung injury in mice with lethal endotoxemia. Exp Anim. 2019;68(4):559-68.

26. Smith $P$, Jeffers $L A$, Koval $M$. Effects of different routes of endotoxin injury on barrier function in alcoholic lung syndrome. Alcohol. 2018;80:81-9.

27. Mokra D, Kosutova P. Biomarkers in acute lung injury. Respir Physiol Neurobiol. 2015;209:52-8.

28. Stormann P, Lustenberger T, Relja B, Marzi I, Wutzler S. Role of biomarkers in acute traumatic lung injury. Injury. 2017;48(11):2400-6.

29. Boshtam M, Asgary S, Kouhpayeh S, Shariati L, Khanahmad H. Aptamers against pro- and anti-inflammatory cytokines: a review. Inflammation. 2017; 40(1):340-9.

30. Qu L, Chen C, Chen Y, Li Y, Tang F, Huang H, He W, Zhang R, Shen L. Highmobility group box 1 (HMGB1) and autophagy in acute lung injury (ALI): a review. Med Sci Monit. 2019;25:1828-37.

\section{Publisher's Note}

Springer Nature remains neutral with regard to jurisdictional claims in published maps and institutional affiliations.

Ready to submit your research? Choose BMC and benefit from:

- fast, convenient online submission

- thorough peer review by experienced researchers in your field

- rapid publication on acceptance

- support for research data, including large and complex data types

- gold Open Access which fosters wider collaboration and increased citations

- maximum visibility for your research: over $100 \mathrm{M}$ website views per year

At BMC, research is always in progress.

Learn more biomedcentral.com/submissions 